\title{
Analisis Metode Analytic Hierarchy Process Dalam Sistem Pendukung Keputusan Pemilihan Taruna Berprestasi
}

\author{
Lisda Juliana Pangaribuan ${ }^{1, *}$, Tiara Sylvia ${ }^{2}$, Liber Tommy Hutabarat ${ }^{2}$ \\ ${ }^{1}$ Program Studi Manajemen Informatika, AMIK Medan Business Polytechnic, Medan, Indonesia \\ ${ }^{2}$ Program Studi Pemanduan Lalu Lintas Udara, Politeknik Penerbangan, Medan, Indonesia \\ Email: ${ }^{1}$ lisdajuliana@gmail.com, ${ }^{2}$ tangoe_sierra@yahoo.co.id, ${ }^{3, *}$ limasodara@gmail.co.id \\ Email Penulis Korespondensi: lisdajuliana@gmail.com
}

\begin{abstract}
Abstrak-Proses pemilihan taruna berprestasi merupakan masalah yang multi kriteria, sehingga untuk mendapatkan calon taruna yang berprestasi secara obyektif diperlukan sistem pendukung keputusan dengan menggunakan berbagai kriteria. Sebagai apresiasi terhadap prestasi, beberapa perguruan tinggi memberikan beasiswa bagi taruna berprestasi. Namun, beberapa universitas memilih siswa berprestasi hanya berdasarkan IPK. Penelitian ini bertujuan untuk menganalisis penerapan metode Analytic Hierarchy Process (AHP) dalam Sistem Pendukung Keputusan pemilihan taruna sehingga dapat ditentukan calon taruna yang berprestasi secara obyektif. Karena jumlah calon taruna berprestasi banyak maka nilai Random Indeks(IR) diperoleh dari tabel IR dengan matriks $>15$. Penelitian ini menggunakan 4 kriteria yaitu kriteria IPK dengan eigen vektor $=0.111$, Karya ilmiah dengan eigen vektor $=0.563$, ekstrakurikuler dengan eigen vektor $=0,246$ Kemampuan Bahasa Asing dengan eigen vektor $=0,08$. Dari hasil penelitian diperoleh nilai $\mathrm{CR}=-0,987<=0,1$, maka Nilai Perbandingan kriteria konsisten. Hasil penelitian menunjukkan bahwa terdapat perbedaan rangking taruna berprestasi di Politeknik Penerbangan Medan menurut IPK dan metode AHP.
\end{abstract}

Kata Kunci: AHP; SPK; Random Indeks; Eigen Vektor; Bobot Kriteria

\begin{abstract}
Process of selecting outstanding cadets is a multi-criteria problem, so get objectively achieving cadets, a decision support system with multiple criteria is needed. As an appreciation for achievement, a few universities provide scholarships for high achieving students. However, a few universities choose outstanding students based only on GPA. This study aims to analyze the application of the Analytic Hierarchy Process (AHP) method in the Decision Support System for the selection of cadets so that objectively achieving candidates can be determined. Because the number of prospective cadets with many achievements, Random Index (IR) value is obtained from IR table $>15$. This study uses 4 criteria, namely the GPA criteria with eigenvectors $=0.111$, Scientific works with eigenvectors $=0.563$, extracurricular (Achievement) with eigen vector $=$ 0.246 Foreign language proficiency with eigenvector $=0.08$. From the research results obtained the value of $\mathrm{CR}=-0,987<=$ 0.1 , then the value of the comparison criteria is consistent. The results showed that there were differences in the ranking of outstanding cadets at the Medan Aviation Polytechnic according to the GPA and the AHP method.
\end{abstract}

Keywords: Analytic Hierarchy Process; Decision Support System; Index Random; Eigen Vector; Criteria Weights.

\section{PENDAHULUAN}

Prestasi mahasiswa menjadi bagian penting dari akreditasi program studi dan akreditasi institusi dibuktikan adanyanya tabel prestasi mahsiswa dalam lembar kerja akreditasi. Untuk memicu prestasi, maka banyak Perguruan Tinggi yang memberikan beasiswa bagi mahasiswa yang berprestasi. Namun banyak Perguruan Tinggi yang memilih mahasiswa berprestasi hanya berdasarkan IPK, sementara persaingan IPK khususnya di Poltekbang medan sangat ketat dan menurut pedoman Pemilihan mahasiswa berprestasi (PILMAPRES) Dirjen Belmawa KEMENRISTEKDIKTI tahun 2017 tidak hanya IPK saja[1]. Proses pemilihan taruna berprestasi merupakan permasalahan yang multikriteria, sehingga untuk mendapatkan taruna yang berprestasi secara objektif diperlukan sebuah sistem pendukung keputusan dengan multikriteria. Untuk itu, diperlukan suatu Sistem Pendukung Keputusan (SPK) dengan menggunakan metode AHP yang dapat memperhitungkan segala kriteria yang mendukung pengambilan keputusan pemilihan taruna dengan melakukan perangkingan untuk menentukan taruna berprestasi[2][3]. Menurut Alonso \& Lamata metode AHP mampu menghitung 39 dimensi Random Index (RI)[4]. Metode AHP juga dapat membantu pengambil keputusan lebih baik pada keputusan pada banyak tujuan[5].

Dalam penelitian ini, disusun beberapa kriteria dan alternatif untuk membangun Sistem Pendukung Keputusan dalam mengolah data-data taruna untuk menentukan taruna berprestasi tingkat perguruan tinggi. sehingga penelitian ini dapat menjadi tolak ukur dalam menentukan taruna berprestasi dengan hasil keputusan lebih objektif dan dapat dipertanggungjawabkan. Penelitian ini menggunakan menggunakan nilai Random Indeks > 15 dan sistem dibangun dengan Bahasa pemrograman PHP dan Database dibangun menggunakan mysql[6],[7].

Sistem Pendukung Keputusan(SPK) merupakan sistem informasi spesifik yang menyediakan informasi, pemodelan, dan pemanipulasian data yang digunakan untuk membantu pengambilan keputusan dalam situasi yang semistruktur dan situasi yang terstruktur[8]. Dengan kata lain SPK adalah suatu sistem informasi berbasis komputer yang melakukan pendekatan untuk menghasilkan berbagai alternatif keputusan untuk membantu pihak tertentu dalam menangani permasalahan dengan menggunakan data dan model sehingga memberikan alternatif keputusan yang akan diserahkan kepada user untuk mengambil keputusan[9]. 
Metode AHP membantu memecahkan persoalan yang kompleks dengan menstruktur suatu hirarki kriteria, pihak yang berkepentingan, hasil dengan menarik berbagai pertimbangan guna mengembangkan bobot atau prioritas[10]. Penelitian tentang mahasiswa berprestasi telah lebih dahulu diteliti oleh Diah Herawatie dengan hasil adanya perbedaan perangkingan Mawapres sesuai dengan aturan Dikti (metode standard) dan perankingan dengan metode TOPSIS dan Fuzzy TOPSIS[11]. Kemudian prestasi siswa kembali diteliti dengan metode VIKOR dan TOPSIS. Hasil yang diperoleh adalah tingkat akurasi yang tertinggi sebesar $80 \%$ dengan menggunakan TOPSIS[12]. Kemudian A.Wijaya(2015) meneliti mahasiswa terbaik menggunakan metode Metode Simple Additive Weighting (SAW) dan mengatakan bahwa SAW adalah metode yang dapat untuk menentukan lulusan mahasiswa terbaik, karena metode tersebut dapat memberikan solusi dalam menentukan lulusan mahasiswa terbaik berdasarkan 4 kriteria yang telah ditentukan yaitu Indek Prestasi Kumulatif (IPK), masa studi, tidak ada nilai D, Nilai C maksimal 1[13], namun pada metode SAW tidak ditentukan kriteria IPK terendah.

Sebagai bahan rujukan, penulis melakukan study literature terhadap beberapa hasil penelitian tentang metode AHP untuk masalah yang berbeda. Penelitian berjudul "DSS using AHP in Selection of Lecturer" menggunakan metode AHP dalam pemilihan dosen di STAIN Batsangkar. Penelitian ini menunjukkan bahwa metode AHP dapat menghasilkan keputusan yang optimal dalam pemilihan dosen sehingga AHP direkomendasikan untuk diterapkan dalam pengambilan keputusan untuk mendapatkan hasil yang optimal[14]. Metode AHP digunakan dalam penelitian untuk pemilihan plot untuk proyek real estat yang terletak di kota Valledupar, Kolombia. Hasil penerapan AHP digunakan untuk membantu pemilihan plot dalam sebuah portofolio alternatif untuk mengembangkan proyek real estat, selain itu penggunaan AHP sebagai alat untuk pengambilan keputusan memberikan lebih banyak transparansi dalam proyek konstruksi[15].

\section{METODOLOGI PENELITIAN}

\subsection{Tahapan Penelitian}

Tahapan yang dilakukan dalam penelitian ini adalah pengumpulan data, analisis data, perancangan SPK dan Implementasi sistem.

\subsection{Pengumpulan Data}

Dari hasil wawancara dan observasi diperoleh populasi dalam penelitian ini adalah seluruh Taruna Poltekbang Medan yang terdiri dari 3 Program Studi (Prodi) yaitu Prodi PLLU, Prodi TNU dan Prodi TLB untuk 3 angkatan. Prodi PLLU sejumlah 71 orang, Prodi TNU sejumlah 67 orang dan Prodi TLB berjumlah 62 orang sehingga total keseluruhan populasi adalah 200 orang.

\subsection{Analisis Data}

Untuk memperoleh Taruna berprestasi dilakukan analisis data dengan metode AHP. Analisis dilakukan terhadap bobot kriteria masing-masing alternatif sesuai dengan algotitma AHP [16], dengan langkah-langkah :

1. Mendefinisikan masalah dan menentukan solusi yang diinginkan.

2. Membuat struktur hierarki yang diawalai dengan tujuan utama

3. Membuat matrik perbandingan berpasangan yang menggambarkan kontribusi relatif atau pengaruh setiap elemen terhadap tujuan atau kriteria yang setingkat di atasnya seperti Tabel1.

Tabel 1. Matriks Perbandingan Berpasangan

\begin{tabular}{ccccc}
\hline & Kriteria1 & Kriteria2 & Kriteria3 & Kriteria n \\
\hline Kriteria1 & K11 & K12 & K13 & K1n \\
Kriteria2 & K21 & K22 & K23 & K2n \\
Kriteria3 & K31 & K33 & K33 & K3n \\
Kriteria $m$ & K m1 & Km2 & Km3 & Kmn \\
\hline
\end{tabular}

4. Mendefinisikan perbandingan berpasangan sehingga diperoleh jumlah penilai seluruhnya sebanyak $n \mathrm{x}$ [(n-1)/2] buah, dimana $\mathrm{n}$ adalah banyaknya elemen yang dibandingkan. Skala penilaian perbandingan berpasangan dapat dilihat pada tabel 2.

5. Menghitung nilai eigen dan menguji konsistensinya. Jika tidak konsisten maka pengambilan data diulangi.

6. Mengulangi langkah 3,4, dan 5 untuk seluruh tingkat hierarki.

7. Menghitung vektor eigen dari setiap matriks perbandingan berpasangan yang merupakan bobot setiap elemen untuk penentuan prioritas elemen-elemen pada tingkat hierarki terendah sampai mencapai tujuan. Penghitungan dilakukan lewat cara menjumlahkan nilai setiap kolom yang bersangkutan untuk memperoleh normalisasi matriks, dan menjumlahkan nilai-nilai dari setiap baris dan membaginya dengan jumlah elemen untuk mendapatkan rata-rata. Apabila A adalah matriks perbandingan berpasangan, maka vektor bobot yang berbentuk:

$$
(\mathrm{A})(\mathrm{wT})=(\mathrm{n})(\mathrm{wT})
$$




\section{JURNAL MEDIA INFORMATIKA BUDIDARMA}

Volume 5, Nomor 1, Januari 2021, Page 344-351

ISSN 2614-5278 (media cetak), ISSN 2548-8368 (media online)

Available Online at https://ejurnal.stmik-budidarma.ac.id/index.php/mib DOI 10.30865/mib.v5i1.2758

8. Menormalkan setiap kolom j dalam matriks A, sedemikian hingga:

9. Hitung nilai rata-rata untuk setiap baris i dalam A':

$$
\sum(i,) i=1 \text { sebut sebagai A'. }
$$

$$
\text { wi }=1 / \mathrm{n} \sum \mathrm{I} \text { a }(\mathrm{ij})
$$

Dimana wi adalah bobot tujuan ke-i dari vektor bobot.

10. Memeriksa konsistensi hirarki.

Misal A adalah matriks perbandingan berpasangan dan w adalah vektor bobot, maka konsistensi dari vektor bobot $\mathrm{w}$ dapat diuji dengan:

a. Hitung: (A)(wT)

b. Hitung indeks konsistensi

c. Indeks random RIn adalah nilai rata-rata CI yang dipilih secara acak pada A

d. Hitung rasio konsistensi

Tabel 2. Skala penilaian perbandingan berpasangan [17]

\begin{tabular}{cll}
\hline Tingkat Kepentingan & Nilai perbandingan antar kriteria & Nilai kebalikan perbandingan antar kriteria \\
\hline 1 & Sama penting dengan & 1 \\
2 & Mendekati sedikit lebih penting & $1 /$ mendekati sedikit lebih penting dari $(0,5)$ \\
3 & Sedikit lebih penting dari & $1 /$ sedikit lebih penting dari $(0,333)$ \\
4 & Mendekati lebih penting dari & $1 /$ mendekati lebih penting dari $(0,25)$ \\
5 & Lebih penting dari & $1 /$ lebih penting dari $(0,2)$ \\
6 & Mendekati sangat penting dari & $1 /$ mendekati sangat penting dari $(0,167)$ \\
7 & Sangat penting dari & $1 /$ sangat penting dari $(0,143)$ \\
8 & Mendekati mutlak dari & $1 /$ mendekati mutlak dari $(0,125)$ \\
9 & Mutlak sangat penting dari & $1 /$ mutlak sangat penting dari $(0,1)$ \\
\hline
\end{tabular}

\subsubsection{Perancangan SPK}

Tahapan Perancangan SPK dapat dilihat pada gambar 1.

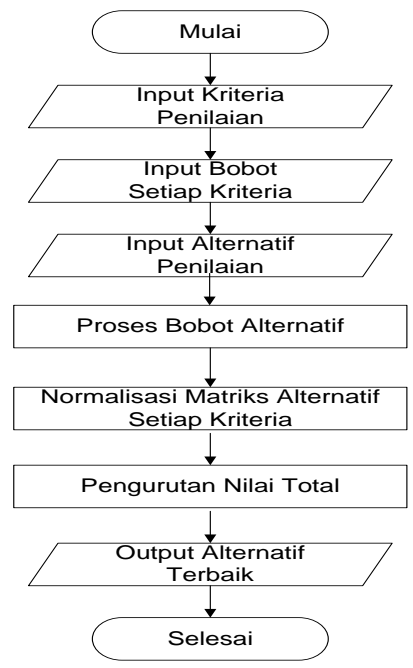

\subsubsection{Kriteria dan Pembobotan}

Gambar 1. Tahapan Perancangan SPK

Kriteria-kriteria yang menjadi bahan perhitungan atau pertimbangan adalah C1:IPK, C2:Karya tulis ilmiah, C3: Prestasi / kemampuan yang diunggulkan(Kegiatan eksul) dan C4:Kemampuan Bahasa Asing(B.Inggris).

a.Kriteria IPK

Bobot dari kriteria IPK menurut Panduan Akademik Poltekbang Medan tahun 2019 seperti tabel 3.

Tabel 3. Bobot Kriteria IPK

\begin{tabular}{llc}
\hline \multicolumn{1}{c}{ Nilai Kriteria $(\mathrm{C})$} & \multicolumn{1}{c}{ Keterangan } & Nilai \\
\hline $\mathrm{C}>=3.51$ & Lulus Dengan Pujian/ LDP & 5 \\
$\mathrm{C}>=3.31$ & Lulus Sangat Memuaskan/ LSM & 4 \\
$\mathrm{C}>=2.71$ & Lulus Memuaskan/ LM & 3 \\
$\mathrm{C}>=2.00$ & Lulus Kurang/ LC & 2 \\
$\mathrm{C}>=0.00$ & Tidak Lulus / TL & 1 \\
\hline
\end{tabular}




\section{JURNAL MEDIA INFORMATIKA BUDIDARMA}

Volume 5, Nomor 1, Januari 2021, Page 344-351

ISSN 2614-5278 (media cetak), ISSN 2548-8368 (media online)

Available Online at https://ejurnal.stmik-budidarma.ac.id/index.php/mib

DOI 10.30865/mib.v5i1.2758

b.Kriteria Karya Tulis Ilmiah

Bobot dari kriteria karya ilmiah menurut Panduan Akademik Poltekbang Medan tahun 2019 seperti tabel 4.

Tabel 4. Bobot Kriteria Karya Tulis Ilmiah

\begin{tabular}{llcc}
\hline \multicolumn{1}{c}{ Nilai Kriteria $(\mathrm{C})$} & & Keterangan & Nilai \\
\hline $\mathrm{C}>=90$ & A & 5 \\
$\mathrm{C}>=80$ & AB & 4 \\
$\mathrm{C}>=70$ & B & 3 \\
$\mathrm{C}>=65$ & C & 2 \\
$\mathrm{C}>=0.00$ & D & 1 \\
\hline
\end{tabular}

c. Kriteria Prestasi / kemampuan yang diunggulkan(Kegiatan eksul)

Bobot dari kriteria Prestasi/Kemampuan yang diunggulkan (Kegiatan eksul) menurut Febriansyah(2015) [18] seperti tabel 5.

Tabel 5. Bobot Kriteria Prestasi

\begin{tabular}{llc}
\hline \multicolumn{1}{c}{ Nilai Kriteria $(\mathrm{C})$} & \multicolumn{1}{c}{ Keterangan } & Nilai \\
\hline $\mathrm{C}=$ Tingkat Internasional & Prestasi Tingkat Internasional & 5 \\
$\mathrm{C}=$ Tingkat Nasional & Prestasi Tingkat Nasional & 4 \\
$\mathrm{C}=$ Tingkat Regional & Prestasi Tingkat Regional atau prestasi tingkat propinsi & 3 \\
$\mathrm{C}=$ Tingkat Propinsi & Prestasi Tingkat Propinsi & 2 \\
$\mathrm{C}<=$ Tingkat Kabupaten/Kota & Prestasi Tingkat Kabupaten/kota & 1 \\
\hline
\end{tabular}

d.Kemampuan Bahasa Asing(B.Inggris)

Bobot dari kriteria Kemampuan Bahasa Asing menurut Darmastuti (2013)[19] dapat dilihat pada tabel 6.

Tabel 6. Bobot Kriteria Kemampuan Bahasa Asing (B.Inggris)

\begin{tabular}{llc}
\hline \multicolumn{1}{c}{ Nilai Kriteria $(\mathrm{C})$} & \multicolumn{1}{c}{ Keterangan } & Nilai \\
\hline $\mathrm{C}>=521$ & Unggul/ Excellent & 5 \\
$\mathrm{C}>=481$ & Sangat Baik/ Very Good & 4 \\
$\mathrm{C}>=421$ & Baik/Good & 3 \\
$\mathrm{C}>=311$ & Cukup/Fair & 2 \\
$\mathrm{C}<=310$ & Kurang/Poor & 1 \\
\hline
\end{tabular}

\section{HASIL DAN PEMBAHASAN}

\subsection{Analisis Metode AHP Terhadap Taruna Berprestasi}

Langkah pertama: mendefenisikan Nilai Kriteria yaitu IPK, Karya ilmiah, Prestasi Ekskul dan Nilai Bahasa Asing yang diperoleh dari Nilai Toefl dan menetukan Nilai alternative.

Langkah ke dua: melakukan pembobotan kretria terhadap data siswa sehingga diperoleh hasil Nilai bobot Kriteria.

Langkah ke tiga: menentukan Prioritas Elemen dengan membandingkan elemen secara berpasangan sesuai kriteria yang diberikan dengan Skala nilai berpasangan pada Tabel2 sehingga diperoleh matriks perbandingan antar kriteria dapat dilihat pada tabel 7.

Tabel 7. Matriks Perbandingan Antar Kriteria

\begin{tabular}{ccccc}
\hline $\begin{array}{c}\text { Perbandingan Antar } \\
\text { Kriteria }\end{array}$ & C1 & C2 & Kriteria & C4 \\
\hline C1 & 1,00 & 0,2 & 0,25 & 2 \\
C2 & 5,00 & 1 & 4 & 5 \\
C3 & 4,00 & 0,25 & 1 & 3 \\
C4 & 0,50 & 0,20 & 0,33 & 1 \\
Jumlah & 10,50 & 1,65 & 5,58 & 11 \\
\hline
\end{tabular}

Langkah ke empat: menjumlahkan Matriks Perbandingan Berpasangan Antar Kriteria sehingga diperoleh nilai Bobot Kriteria seperti tabel 8.

Tabel 8. Penghitungan Matriks Penjumlahan Bobot Kriteria

\begin{tabular}{cccccc}
\hline Kriteria & C1 & C2 & C3 & C4 & Jumlah \\
\hline C1 & 0,1108 & 0,1127 & 0,0615 & 0,1597 & 0,4447 \\
\hline
\end{tabular}




\begin{tabular}{llllll}
\hline C2 & 0,5538 & 0,5633 & 0,9843 & 0,3993 & 2,5007 \\
C3 & 0,4430 & 0,1408 & 0,2461 & 0,2396 & 1,0695 \\
C4 & 0,0554 & 0,1127 & 0,0820 & 0,0799 & 0,3299 \\
\hline
\end{tabular}

Langkah ke lima: mengetahui Rasio Konsistensi. Untuk mengetahui rasio konsistensi pertama dihitung Pricipal Eigen Value ( $\lambda$ max) matrix dengan hasil $\mathrm{C} 1=0,5554 ; \mathrm{C} 2=3,064 ; \mathrm{C} 3=1,3156 ; \mathrm{C} 4=0,4098$ sehingga diperoleh Rata-rata $(\lambda \max )=1,3362 ;$ Consistency Index $(\mathrm{CI})=(1,3362-4) /(4-1)=-0,888$. Sehingga batas toleransi ketidak konsistenan ditentukan oleh nilai Random Consistency Index (CR) yang diperoleh dengan rumus $\mathrm{CR}=\mathrm{CI} / \mathrm{RI}$, Jadi untuk $\mathrm{n}=4, \mathrm{RI}=0.9$. $\mathrm{CR}=-0,888 / 0.9=-0,987<=0,1$ (bisa diterima). Dari hasil perhitungan $\mathrm{CR}$ lebih kecil atau sama dengan $10 \%$, maka ketidak konsistenan masih bisa diterima.

Langkah ke enam: tentukan Prioritas Subkriteria. Untuk kriteria IPK dengan IR $24=1,6577$ maka CR $=-$ $1 / 1,6577=-0,60<=0,1$ maka kekonsistenan kriteria IPK dapat diterima. Kriteria Karya Ilmiah Nilai CI $=-0,998$ dan $\mathrm{CR}=-0,602<=0,1$ ketidak konsistenan masih bisa diterima. Kriteria Prestasi Ekskul Nilai $\mathrm{Cl}=-1$ dan $\mathrm{CR}=-$ $0,6<=0,1$ maka Nilai kekonsistenan kriteria Prestasi ekskul bias diterima. Kriteria Kemampuan Bahasa Asing diperoleh nilai $\mathrm{Cl}=-1$ dan nilai $\mathrm{CR}=-0,6$.

Langkah ke tujuh: menghitung Hasil Akhir Konsistensi yang didapat dengan mengelompokkan setiap nilai prioritas setiap kriteria untuk tiap-tiap alternatif yang nantinya dikali dengan bobot nilai dari tiap kriteria. Dari Hasil Pengelompokan Nilai Perioritas diperoleh nilai Vector Eigen Kriteria C1 : IPK = 0,111; Vector Eigen Kriteria C2 : Karya Tulis ilmiah $=0,563$; Vector Eigen Kriteria C3 : Prestasi ekskul $=0,246$; Vector Eigen Kriteria C1 : Kemampuan Bahasa Asing/B.Inggris= 0,08.

Hasil akhir Nilai kolom $\mathrm{C} 1=$ Bobot Kriteria $\mathrm{C} 1 *$ Nilai Masing-masing alternative kemudian dilakukan penjumlahan nilai dari seluruh Kriteria $(\mathrm{C} 1+\mathrm{C} 2+\mathrm{C} 3+\mathrm{C} 4)$.

Dari hasil perhitungan dapat diketahui 3 orang taruna berprestasi prodi PLLU adalah : T2 (Ade Ramadhani) dengan Nilai AHP $=0,0584$; T3 (Alya Salfanora) dengan Nilai AHP $=0,0578$ dan T6 (Dicky Ferdi) dengan Nilai AHP $=0,0570$. Sedangkan Berdasarkan IPK, 3 orang taruna Prodi PLLU dengan IPK Tertinggi berturut-turut : Adeline Fricyllia Minar dengan IPK = 3,40 ( Menurut Metode AHP= rank 9), Ade Ramadhani dengan IPK = 3,372 (Menurut Metode AHP= rank 1), Alya S. dengan IPK $=3,36$ ( Menurut Metode AHP= rank 2).

Taruna berprestasi prodi TLB menurut perhitungan metode AHP adalah : T11 (Suci Dina M. Panjaitan) dengan Nilai AHP = 0,087; T17 (Bob Verson) dengan Nilai AHP =0,06; T9 (Jatra Teguh Widodo) dengan Nilai AHP $=0,06$ sedangkan Berdasarkan IPK, 3 orang taruna Prodi TLB dengan IPK Tertinggi berturut-turut :

Yoga Nugraha dengan IPK $=3,52$ (Menurut Metode AHP= rank 15), Adam dengan IPK $=3,49$ (Menurut Metode AHP= rank 9), Atika Mega Lestari S. dengan IPK = 3,46 (Menurut Metode AHP= rank 8).

Taruna berprestasi prodi TNU menurut perhitungan metode AHP adalah : T5 (LATHIFAH RAHMAH DAMANIK) dengan Nilai AHP $=0,055 ;$ T1 (ALFANDY NURRAHMAN) dengan Nilai AHP $=0,054 ; \quad$ T19 (TRY FEBRIZA C. MANURUNG) dengan Nilai AHP $=0,0535$ sedangkan Berdasarkan IPK, 3 orang taruna Prodi TLB dengan IPK Tertinggi berturut-turut :Alfandy Nurrahman dengan IPK $=3,52$ ( Menurut Metode AHP= rank 2), Rizky Febrizal Sembiring dengan IPK = 3,46 (Menurut Metode AHP= rank 18), Josua Williams dengan IPK $=3,41$ (Menurut Metode AHP= rank 7). Pada Prodi TLB dapat dilihat ada perbedaan antara Pengurutan berdasarkan metode AHP dengan IPK.

Dari hasil Perhitungan untuk 3 program studi dapat dilihat ada perbedaan significant antara Pengurutan berdasarkan metode AHP dengan IPK. Dari hasil perhitungan terdapat nilai bobot yang sama pada beberapa taruna, hal ini disebabkan penilaian bobot kriteria yang dilakukan dengan metode AHP berdasarkan skala kriteria bukan sepenuhnya berdasarkan nilai masing-masing kriteria.

\subsection{Implementasi Metode AHP dalam Sistem Pendukung Keputusan (SPK)}

Sistem Pendukung Keputusan dibangun dengan bahasa Pemrograman PHP dan DBMS Mysql. Untuk menggunakan SPK Pemilihan Taruna Berprestasi ada 2 hak akses pada menu login yaitu : Admin dan User seperti pada gambar 2 .

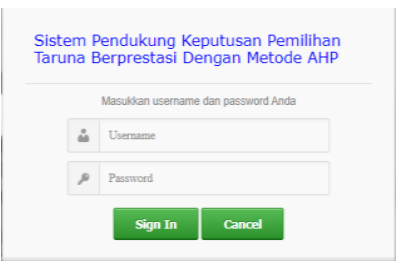

Gambar 2. Menu Login

Login Admin pada Gambar 3 dapat menginput Nilai Kriteria dan Nilai Alternatif (Nama Taruna yang ikut Pemilihan) seperti Gambar 4 dan Gambar 5. 
JURNAL MEDIA INFORMATIKA BUDIDARMA

Volume 5, Nomor 1, Januari 2021, Page 344-351

ISSN 2614-5278 (media cetak), ISSN 2548-8368 (media online)

Available Online at https://ejurnal.stmik-budidarma.ac.id/index.php/mib

DOI 10.30865/mib.v5i1.2758

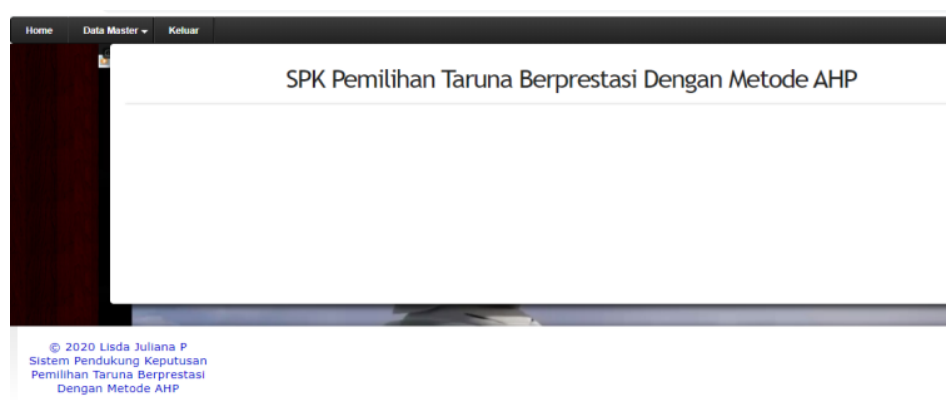

Gambar 3. Menu Login Admin

Nilai Kriteria

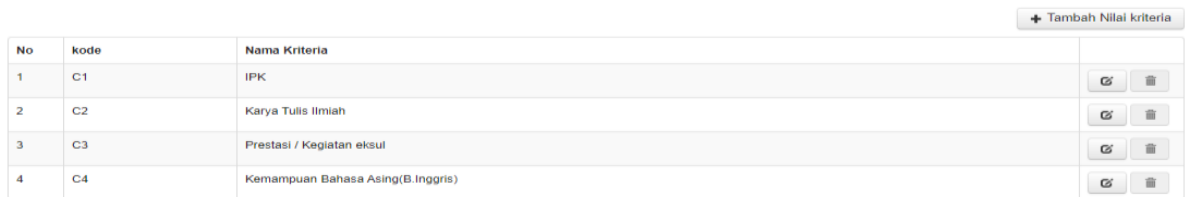

Gambar 4. Input Kriteria

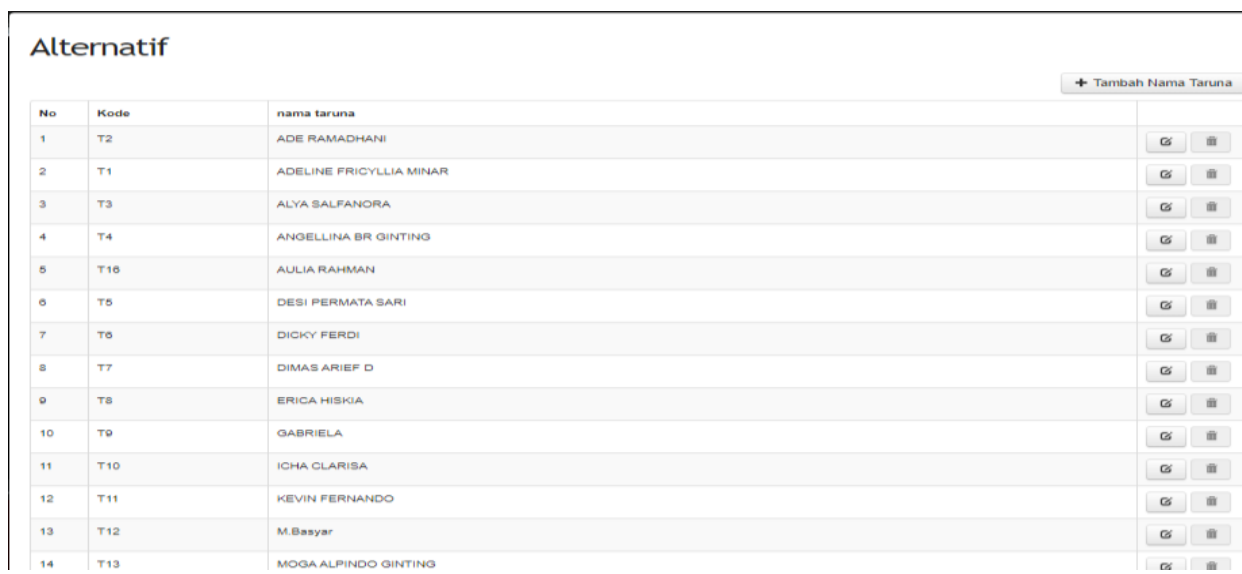

Gambar 5. Menu Input Alternatif

Setelah Nilai kriteria dan alternative di input ke sistem, keluar dari login admin dan masuk ke login user Setelah login akan tampil menu user yang terdiri dari : Home ( menu utama), Kriteria taruna (Untuk menginput nilai perbandingan kriteria) seperti gambar 6 .

Nilai Perbandingan Kriteria

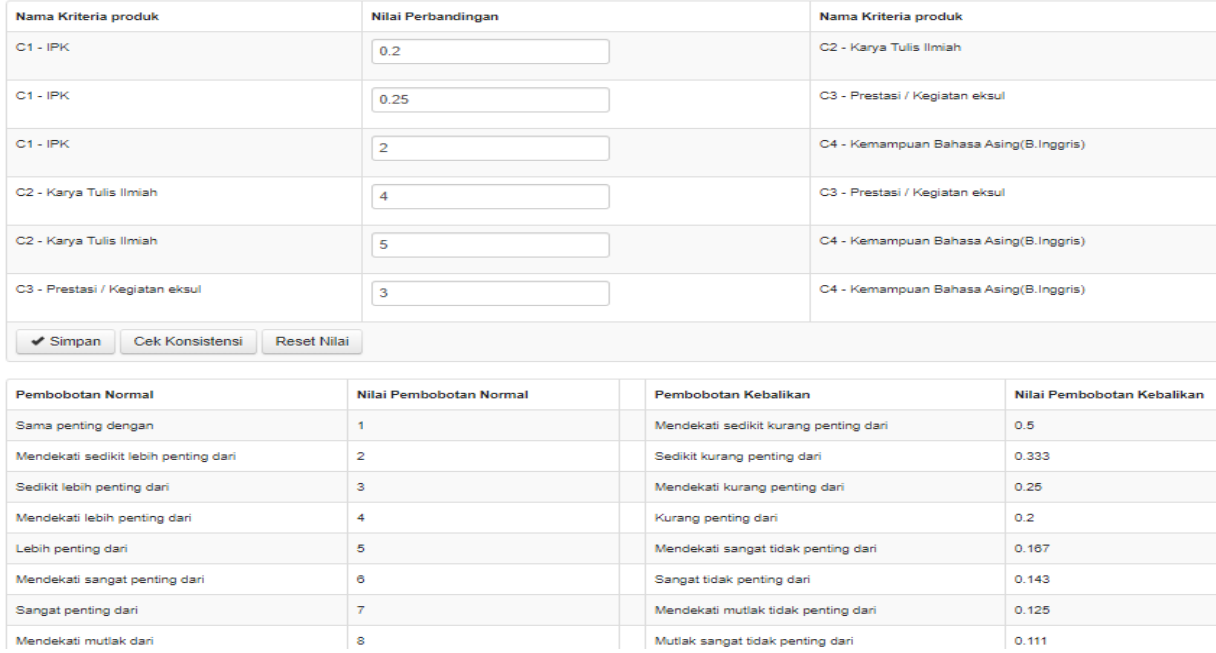

Gambar 6. Menu Nilai Perbandingan kriteria taruna 
ISSN 2614-5278 (media cetak), ISSN 2548-8368 (media online)

Available Online at https://ejurnal.stmik-budidarma.ac.id/index.php/mib DOI 10.30865/mib.v5i1.2758

Penilaian taruna: Menginput nilai perbandingan IPK, nilai Perbandingan Karya ilmiah, Nilai Perbandingan Prestasi eksul dan nilai perbandingan Kemampuan bahasa asing. Selanjutnya setelah seluruh nilai perbandingan taruna diinput pada akhir menu akan tampil daftar Penilaian Pembobotan Normal dan Penilaian Pembobotan Kebalikan seperti gambar7.

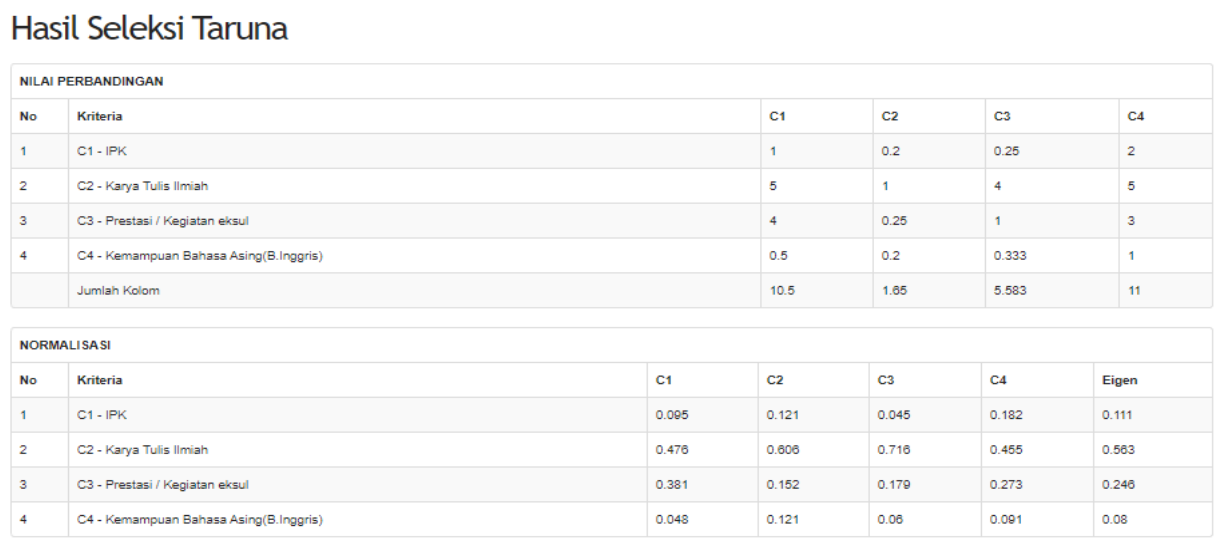

Gambar 7. Nilai Perbandingan Kriteria dan Normalisasi

kemudian klik menu Ranking Taruna akan muncul Hasil Seleksi taruna seperti gambar 8.

\begin{tabular}{|c|c|c|c|c|c|c|c|}
\hline No & Alternatif & C1 & $\mathrm{C} 2$ & C3 & $\mathrm{C} 4$ & Nilai & Rank \\
\hline & Vektor Eigen & 0.111 & 0.583 & 0.248 & 0.08 & & \\
\hline 1 & T1 - ADELINE FRICYLLIA MINAR & 0.063 & 0.032 & 0.048 & 0.039 & 0.04 & 8 \\
\hline 2 & T10 - ICHA CLARISA & 0.031 & 0.032 & 0.024 & 0.039 & 0.03 & 23 \\
\hline 3 & T11 - KEVIN FERNANDO & 0.031 & 0.032 & 0.048 & 0.021 & 0.035 & 18 \\
\hline 4 & T12-M.Basyar & 0.031 & 0.032 & 0.048 & 0.038 & 0.037 & 16 \\
\hline 5 & T13 - MOGAALPINDO GINTING & 0.031 & 0.065 & 0.024 & 0.107 & 0.055 & 6 \\
\hline 6 & T14 - MORA SAKTIZ.S HASIBUAN & 0.031 & 0.032 & 0.024 & 0.021 & 0.029 & 24 \\
\hline 7 & T15 - PRISTY HAJATI & 0.031 & 0.032 & 0.048 & 0.038 & 0.037 & 15 \\
\hline 8 & T16 - AUUIA RAHMAN & 0.031 & 0.065 & 0.048 & 0.021 & 0.054 & 7 \\
\hline 8 & T17 - SAHAT PARSAULIAN S. & 0.031 & 0.065 & 0.048 & 0.039 & 0.055 & 5 \\
\hline 10 & T18 - SINDI HANI SINGARIMBUN & 0.031 & 0.065 & 0.048 & 0.038 & 0.055 & 4 \\
\hline 11 & T19- SRI TAN JAYAS & 0.031 & 0.032 & 0.048 & 0.038 & 0.037 & 14 \\
\hline 12 & T2 - ADE RAMADHANI & 0.063 & 0.085 & 0.048 & 0.039 & 0.059 & 1 \\
\hline 13 & T20 - ULFANAMIRAS & 0.031 & 0.032 & 0.048 & 0.021 & 0.035 & 18 \\
\hline 14 & T21 - YOSI ANNISA & 0.031 & 0.032 & 0.028 & 0.038 & 0.032 & 22 \\
\hline 15 & T22 - MURSYID RAJA & 0.031 & 0.032 & 0.028 & 0.039 & 0.032 & 21 \\
\hline 16 & T23-RAMU BILL & 0.031 & 0.032 & 0.048 & 0.071 & 0.039 & 11 \\
\hline 17 & T24 - THIRTY MEYDIAN & 0.032 & 0.032 & 0.049 & 0.071 & 0.039 & 10 \\
\hline 18 & T3- ALYA SALFANORA & 0.062 & 0.065 & 0.024 & 0.107 & 0.058 & 2 \\
\hline 18 & T4 - ANGELLINA BR GINTING & 0.063 & 0.032 & 0.047 & 0.039 & 0.04 & 8 \\
\hline 20 & T5 - DESI PERMATA SARI & 0.063 & 0.032 & 0.047 & 0.021 & 0.038 & 13 \\
\hline 21 & TQ - DICKY FERDI & 0.003 & 0.065 & 0.047 & 0.021 & 0.057 & 3 \\
\hline 22 & $T 7$ - DIMAS ARIEF D & 0.063 & 0.032 & 0.024 & 0.021 & 0.033 & 20 \\
\hline 23 & T8- ERICA HISKIA & 0.063 & 0.032 & 0.047 & 0.021 & 0.038 & 12 \\
\hline 24 & TQ - GABRIELA & 0.031 & 0.032 & 0.047 & 0.039 & 0.036 & 17 \\
\hline
\end{tabular}

Gambar 8. Hasil Seleksi Metode AHP

\section{KESIMPULAN}

Pada penelitian ini kriteria yang mempengaruhi penilaian taruna berprestasi di Politeknik Penerbangan Medan adalah IPK dengan bobot kriteria $=0.111$, Karya Tulis ilmiah dengan bobot kriteria $=0.563$, Prestasi ekskul dengan bobot kriteria $=0.246$ Kemampuan Bahasa Asing/B.Inggris dengan bobot kriteria $=0.08$. Penelitian ini menggunakan 4 kriteria yaitu kriteria IPK dengan eigen vektor $=0.111$, Karya ilmiah dengan eigen vektor $=$ 0.563, ekstrakurikuler dengan eigen vektor $=0,246$ Kemampuan Bahasa Asing dengan eigen vektor $=0,08$. Hasil penelitian menunjukkan adanya perbedaan ranking dalam menentukan Taruna Berprestasi berdasarkan IPK dengan Taruna Berprestasi berdasarkan Metode AHP pada tiga program studi di Politeknik Penerbangan Medan. Metode AHP baik dipakai untuk memutuskan mahasiswa berprestasi karena menggunakan beberapa kriteria 
JURNAL MEDIA INFORMATIKA BUDIDARMA

Volume 5, Nomor 1, Januari 2021, Page 344-351

ISSN 2614-5278 (media cetak), ISSN 2548-8368 (media online)

Available Online at https://ejurnal.stmik-budidarma.ac.id/index.php/mib

DOI 10.30865/mib.v5i1.2758

sesuai dengan peraturan yang berlaku. Dalam penentuan ranking taruna terdapat nilai bobot yang sama pada beberapa taruna, hal ini disebabkan penilaian bobot kriteria yang dilakukan dengan metode AHP berdasarkan skala kriteria bukan sepenuhnya berdasarkan nilai masing-masing kriteria. Hasil penelitian menunjukkan nilai $\mathrm{CR}=-0,987<=0,1$, maka Nilai Perbandingan kriteria konsisten.

\section{REFERENCES}

[1] K. Riset, T. Dan, and P. Tinggi, "Pemilihan Mahasiswa Berprestasi Program Sarjana,” 2016.

[2] R. Umar, A. Fadlil, and Y. Yuminah, "Sistem Pendukung Keputusan dengan Metode AHP untuk Penilaian Kompetensi Soft Skill Karyawan," Khazanah Inform. J. Ilmu Komput. dan Inform., vol. 4, no. 1, p. 27, 2018, doi: 10.23917/khif.v4i1.5978.

[3] Bay Haqi, plikasi SPK Pemilihan Dosen Terbaik Metode Simple Additive Weighting (SAW ) dengan Java. Yogyakarta: Depublish, 2019.

[4] T. M. Alonso, J. A., \& Lamata, “judul,” Int. J. Uncertain., vol. 4, no. 14, pp. 445-459, 2006.

[5] P. A. Jusia, Juliana, and Jasmir, "Decision Support System for Supplier Selection using Analytical Hierarchy Process ( AHP ) Method,” Sci. J. Informatics, vol. 4, no. 2, pp. 1-6, 2017.

[6] A. Solichin and S. Kom, Pemrograman Web dengan PHP dan MySQL. Jakarta: Universitas Budi Luhur, 2017.

[7] P. B. Nugroho and I. Indriyanna, Koleksi Buku dari Penerbit GAVAMEDIA, Yogyakarta. Jakarta.

[8] S. Latif A, L., Jamil, M., \& Abbas, Sistem Pendukung Keputusan Teori dan Implementasi. 2018.

[9] A. Sasongko, I. F. Astuti, and S. Maharani, "Pemilihan Karyawan Baru Dengan Metode AHP (Analytic Hierarchy Process)," Inform. Mulawarman J. Ilm. Ilmu Komput., vol. 12, no. 2, p. 88, 2017, doi: 10.30872/jim.v12i2.650.

[10] M. Mursalim and M. Mardainis, "Penerapan Metode AHP Dan TOPSIS Untuk Mengevaluasi Pemohon Kredit Suku Cadang Motor Suzuki (Studi Kasus : PT. Riau Jaya Cemerlang Pekanbaru),” Digit. Zo. J. Teknol. Inf. dan Komun., vol. 7, no. 2, pp. 115-128, 2016, doi: 10.31849/digitalzone.v7i2.603.

[11] D. Herawatie and E. Wuryanto, "Sistem Pendukung Keputusan Pemilihan Mahasiswa Berprestasi dengan Metode Fuzzy TOPSIS," J. Inf. Syst. Eng. Bus. Intell., vol. 3, no. 2, p. 92, 2017, doi: 10.20473/jisebi.3.2.92-100.

[12] R. Putra, I. Werdiningsih, and I. Puspitasari, "Sistem Pendukung Keputusan Pemilihan Siswa Berprestasi di Sekolah Menengah Pertama dengan Metode VIKOR dan TOPSIS," J. Inf. Syst. Eng. Bus. Intell., vol. 3, no. 2, p. 113, 2017, doi: 10.20473/jisebi.3.2.113-121.

[13] A. H. Wijaya, M. L. Terbaik, and P. Keputusan, "SISTEM PENDUKUNG KEPUTUSAN UNTUK MENENTUKAN LULUSAN MAHASISWA TERBAIK DENGAN MENGGUNAKAN METODE SIMPLE ADDITIVE WEIGHTING ( SAW ) DI FAKULTAS TEKNIK UNIVERSITAS,” no. November, pp. 357-366, 2015.

[14] Y. M. Adriyendi, "DSS using AHP in Selection of Lecturer," Int. J. Adv. Sci. Technol., vol. 52, no. 2005-4238, pp. 3544, 2017, [Online]. Available: https://www.earticle.net/Article/A206899.

[15] L. Gutiérrez-Bucheli, J. Vallejo-Borda, and J. Ponz-Tienda, "Application of the Analytic Hierarchy Process (AHP) in the Construction Industry: a Case Study in the Selection of the Plot for a Real Estate Project," VII Elagec, no. November, p. 11, 2016.

[16] A. Munthafa and H. Mubarok, "Penerapan Metode Analytical Hierarchy Process Dalam Sistem Pendukung Keputusan Penentuan Mahasiswa Berprestasi," J. Siliwangi, vol. 3, no. 2, pp. 192-201, 2017.

[17] Kusrini, Konsep dan Aplikasi Sistem Pendukung Keputusan. Yogyakarta: Penerbit Andi, 2017.

[18] F. E. Febriansyah and N. Sari, "Pengembangan Sistem Informasi Pendaftaran Beasiswa Peningkatan Prestasi Akademik ( PPA ) Jurusan Ilmu Komputer Fakultas Matematika dan Ilmu Pengetahuan Alam Universitas Lampung dengan Menerapkan Algoritma Sorting Quick Sort dan Selection Sort,” vol. 3, no. 2, pp. 67-74, 2015.

[19] D. Darmastuti, "Implementasi Metode Simple Additive Weighting ( SAW ) Dalam Sistem Informasi Lowongan Kerja Berbasis Web Untuk Rekomendasi Pencari Kerja Terbaik," J. Sist. dan Teknol. Inf., vol. 16, no. 2, pp. 1-6, 2013, [Online]. Available: http://jurnal.untan.ac.id/index.php/justin/article/view/2658. 